\title{
Hereditary Elliptocytosis
}

National Cancer Institute

\section{Source}

National Cancer Institute. Hereditary Elliptocytosis. NCI Thesaurus. Code C35882.

An inherited blood disorder in which a large number of red blood cells have an elliptical morphology. 